\title{
PENINGKATAN KETERSEDIAAN FOSFAT DAN PRODUKSI TANAMAN KENTANG (Solanum tuberosum L) DENGAN MENGGUNAKAN Talaromyces pinophilus INDIGENOUS DAN PUPUK SP36 PADA ANDISOL TERDAMPAK ERUPSI GUNUNG SINABUNG
}

\section{Mariani Sembiring $^{*}$, Deni Elfiati ${ }^{2}$, Edi Sigit Sutarta ${ }^{3}$ dan T.Sabrina ${ }^{1}$}

1. Departemen Agroekoteknologi Fakultas Pertanian USU, Medan 20155

2. Departemen Kehutanan, Fakultas Pertanian USU, Medan 20155

3. Pusat Penelitian Kelapa Sawit (PPKS), Medan 20158

Corresponding author: mariani.sembiring29@yahoo.com

\begin{abstract}
ABSTRAK
Penelitian ini bertujuan untuk mengetahui pengaruh Jamur pelarut Fosfat, Dosis Pupuk P dan kombinasi jamur Pelarut Fosfat dan Dosis Pupuk P terhadap Pertumbuhan, P-tersedia dan produksi tanaman kentang (Solanum tuberosum L) pada Andisol terdampak erupsi Sinabung. Parameter yang diamati: Berat kering tanaman diukur pada akhir masa vegetatif, Produksi tanaman, Serapan P tanaman dan Analisa P tersedia tanah,dengan metode Bray II diukur pada akhir masa vegetatif. Hasil penelitian menunjukkan bahwa Kombinasi perlakuan Jamur pelarut fosfat ( $T$. pinophilus )dan SP36 berpengaruh terhadap peningkatan P-tersedia pada perlakuan J1P2 yaitu sebesar $71.65 \%$ bila dibanding dengan kontrol walaupun secara statistik tidak berpengaruh nyata. Pada parameter serapan $\mathrm{P}$ tanaman aplikasi perlakuan $T$. pinophilus dan SP36 berpengaruh nyata dalam peningkatan serapan $\mathrm{P}$ tanaman, perlakuan yang terbaik adalah T3P2 tetapi menurun dengan peningkatan dosis SP36 $(\mathrm{P} 3=13 \mathrm{~g})$. Berat kering tanaman perlakuan T3P2 yang terbaik dan menurun dengan meningkatnya dosis SP36 (13 g). Peningkatan produksi tanaman kentang yang tertinggi yaitu J2P1 dengan produksi sebesar 1017.5g sedangkan tanaman kontrol 610 g.Peningkatan produksi tanaman kentang yaitu sebesar $66.8 \%$ lebih tinggi bila dibanding dengan kontrol. Aplikasi $T$. pinophilus sebanyak $20 \mathrm{~mL}$ dan $6.5 \mathrm{~g} \mathrm{SP} 36$ memiliki produksi yang terbaik, produksi menurun dengan peningkatan dosis T. pinophilus dan pupuk SP36.
\end{abstract}

Kata kunci : Andisol, Dosis Pupuk P, tanaman Kentang, Talaromyces pinophilus

\section{PENDAHULUAN}

Gunung Sinabung kembali meletus pada bulan September 2013, Abu vulkanik merupakan bahan material vulkanik jatuhan yang disemburkan ke udara pada saat terjadi letusan. Secara umum komposisi abu vulkanik terdiri atas Silika dan Kuarsa. Balitbangtan (2014) menunjukkan hasil analisis terhadap abu vulkanik berupa komposisi mineral abupasir volkan berupa fragmen batuan (28 $37 \%)$, gelas volkan (22 - 26\%), augsit (8 $13 \%)$, Heperstin (10 - 18\%), labradorit (7 -
$10 \%)$, bintonit (2 - 5\%) dan opak (3-5\%). Bahan-bahan mineral ini bila melapuk akan menjadi sumber unsur hara esensial terutama $\mathrm{Ca}, \mathrm{Mg}, \mathrm{K}, \mathrm{Na}, \mathrm{P}, \mathrm{S}, \mathrm{Fe}$ dan $\mathrm{Mn}$.

Abu vulkanik yang cukup lama menutupi permukaan tanah akan mengendap dan mengeras bergantung pada tingkat ketebalannya. Hal tersebut dapat menyebabkan terganggunya aerase tanah yang berdampak pada kehidupan mikroorganisme dalam tanah. Menurut penelitian yang dilakukan Lubis (2011) menyatakan bahwa abu vulkanik 
berpengaruh nyata menurunkan nilai respirasi mikroorganisme tanah.

Salah satu jenis tanah yang bermasalah dengan keberadaan fosfat adalah Andisol (Darmawijaya, 1990). Andisol sebetulnya mempunyai kandungan $\mathrm{P}$ total relatif tinggi sekitar 160-500 $\mathrm{mg} / 100 \mathrm{~g}$ tanah, tetapi jumlah $\mathrm{P}$ yang tersedia bagi tanaman sangat rendah, hanya sekitar $1 \%$ dari total $\mathrm{P}$ yang terdapat dalam tanah (Sanchez,1992). Hal ini terjadi karena kapasitas jerapan fosfat tanah di atas 85\% (Siefferman, 1992). Menurut Buckman dan Brady, (1982), Andisol mempunyai nilai $\mathrm{pH}$ yang sedikit masam sampai masam, sehingga banyak mengandung $\mathrm{Al}$ dan $\mathrm{Fe}$ ter larut yang akan bereaksi dengan ion fosfat, sehingga ion fosfat menjadi tidak tersedia. Hasil penelitian Muklis (2013) retensi P pada tanah andisol di desa kuta rayat atau sebelah utara gunung sinabung berkisar antara $95,04 \%-99,91 \%$.

Alternatif untuk meningkatkan efisiensi pemupukan fosfat dalam mengatasi rendahnya fosfat tersedia dalam tanah adalah dengan memanfaatkan kelompok mikroorganisme pelarut fosfat dan aplikasi bahan organik, yang dapat melarutkan fosfat tidak tersedia menjadi tersedia sehingga dapat diserap oleh tanaman.

Tanaman hanya dapat menyerap $\mathrm{P}$ dalam bentuk yang tersedia. Unsur P tanah baru dapat tersedia oleh perakaran tanaman atau mikrobia tanah melalui sekresi asam organik oleh akar atau mikrobia. Oleh karena itu mikrobia yang dapat melarutkan $\mathrm{P}$ memegang peranan penting dalam sistem pertanian. Mikroorganisme pelarut fosfat merupakan mikroorganisme yang mempunyai kemampuan mengekstrak fosfat dari bentuk yang tidak larut menjadi bentuk yang tersedia bagi tanaman.

Kemampuan mikroba pelarut $\mathrm{P}$ sangat beragam tergantung jenis dan daya adaptasi terhadap lingkungan barunya. Inokulasi bakteri dan jamur pelarut fosfat yang dilakukan oleh Sahar Hanafiah (1994) mampu meningkatkan $\mathrm{P}$ tersedia tanah rata-rata sebesar $32,11 \%$ dan $137,51 \%$ disamping itu serapan tanaman kedelai meningkat sebesar $94,85 \%$ dan $83,09 \%$ Inokulasi bakteri pelarut fosfat pada tanah Ultisol.

\section{BAHAN DAN METODE}

Penelitian ini dilaksanakan di Desa Kutarayat Kec. Naman Teran Kab Karo( Sebelah Utara Gunung Sinabung). Penelitian ini dilaksanakan dari bulan Juli 2014 - November 2014.

Bahan - Bahan yang digunakan pada penelitian ini adalah isolat Jamur pelarut fosfat (Talaromyces pinophilus) Indigenous yang diisolasi dari rhizosfer tanaman kentang asal Desa Kutarayat yang telah diuji kemampuannya dalam melarutkan fosfat, bibit kentang varitas granola, pupuk urea, SP36, KCl, Pestisida, insektidida dan bahan yang lainnya yang dianggap perlu pada penelitian ini. Alat yang digunakan adalah Cangkol, gembor, timbangan dan alat alat lainnya yang mendukung penelitian ini.

Uji Efektifitas Jamur Pelarut Fosfat (Talaromyces pinophilus) dilaksanakan di desa kutarayat Kec Naman Teran Kab.Karo. Penelitian ini menggunakan Rancangan RAK faktorial dengan perlakuan Jamur Pelarut Fosfat dan dosis pupuk $\mathrm{P}$, tanaman yang digunakan adalah tanaman kentang (Solanum tuberosum L.) Faktor I : Aplikasi Jamur Pelarut Fosfat (Talaromyces pinophilus) terdiri atas $; \mathrm{K}=$ control, $J 1$ = Jamur Pelarut fosfat $10 \mathrm{ml} /$ Tanaman, $\mathrm{J} 2$ = Jamur Pelarut fosfat 20 $\mathrm{ml} /$ Tanaman, $\mathrm{J3}=$ Jamur Pelarut fosfat 30 $\mathrm{ml} /$ Tanaman

Faktor keduan adalah Dosis Pupuk P (pupuk yang digunakan SP36), yaitu ; P1 = $50 \%$ dosis Rekomendasi pupuk P (6.5 gr/Tanaman),P2=75 \% dosis Rekomendasi pupuk P ( 9.75 gr/tanaman), P3 = $100 \%$ dosis Rekomendasi pupuk $\mathrm{P} \quad(13$ gr/tanaman). 


\section{Pelaksanaan Penelitian}

Pembersihan areal, pengolahan tanah dan pembuatan guludan dilakukan sesuai dengan cara setempat. Pembuatan guludan dilakukan sesuai dengan jumlah unit percobaan. masing-masing berukuran 0,6 m x 4,20 m. jarak antar guludan dalam blok $30 \mathrm{~cm}$ dan jarak antar blok $50 \mathrm{~cm}$.
Aplikasi
Pemupukan dan pemeliharaan Aplikasi pupuk dasar berupa Urea, SP36 dan KCl.dosis pupuk P yang digunakan adalah seduai dengan perlakuan sedangkan dosis untuk Urea dan $\mathrm{KCl}$ yaitu $100 \mathrm{~kg} \mathrm{~N} / \mathrm{ha} ; 100 \mathrm{~kg} \mathrm{~K} 20 / \mathrm{ha}$. Pemeliharaan dilakukan berupa penyemprotan insektisida dan fungisida serta mencegah tumbuhnya gulma.

Persiapan Isolat mikroba Pelarut fosfat Persiapan isolat mikroba pelarut fosfat dilakukan di Labolatorium Biologi tanah Fak Pertanian USU yaitu dengan cara membuat media cair pykovskaya. Aplikasi Mikroba Pelarut fosfat Aplikasi mikroba pelarut Posfat diaplikasikan di sekitar perakaran dengan dosis dan waktu aplikasi dilakukan 1 Minggu Setelah Tanaman Tumbuh.

Pemanenan penelitian ini dilakukan sampai $60 \%$ tanaman telah berbunga (Masa Vegetatif). Untuk keperluan analisa tanaman dipotong kemudian dimasukkan kedalam amplop kuning dan di bawa kelabolatorium. Untuk melihat produksi penelitian dilanjut sampai 3 bulan tanam (sesuai dengan kreteria panen tanaman kentang).

\section{Parameter yang diamati:}

1. Berat kering tanaman diukur pada akhir masa vegetatif

2. Produksi tanaman pada akhir penelitian

3. Analisa $P$ tersedia tanah,dengan metode Bray II,diukur pada akhir masa vegetatif

4. Serapan P Tanaman

\section{HASIL DAN PEMBAHASAN}

Pada Tabel 1. dapat dilihat pengamatan $\mathrm{P}$-Tersedia perlakuan jamur pelarut fosfat ( $T$. pinophilus) menunjukan bahwa dengan aplikasi jamur pelarut fisfat dapat meningkatkan P-Tersedia bila di banding dengan tanpa aplikasi ( kontrol) yaitu $81.71 \mathrm{~g}$ sedangkan yang diberi jamur pelarut fosfat $(\mathrm{T} 1=$ ) yaitu 125.01 bila dibandingkan dengan kontrol, peningkatan $\mathrm{P}$ tersedia sebesar 56\%. Perlakuan jamur pelarut fosfat tidak berpengaruh nyata terhadap serapan $\mathrm{p}$ tanaman, tetapi dengan aplikasi jamur pelarut fosfat dapat meningkatkan serapan $\mathrm{P}$ tanaman. Pada parameter produksi tanaman perlakuan $\mathrm{T} 1$ lebih tinggi bila dibanding dengan perlakuan yang lainnya bila di lihat dari angka Indeks $28.89 \%$ lebih tinggi bila dibandingkan dengan kontrol. Havlin $d k k$ (1999) Enzim fosfatase berperan utama dalam melepaskan P dari ikatan P-organik. Enzim ini banyak dihasilkan oleh mikroba tanah, terutama yang bersifat heterotrof. Aktivitas fosfatase dalam tanah meningkat dengan meningkatnya $\mathrm{C}$-organik, tetapi juga dipengaruhi oleh $\mathrm{pH}$, kelembaban, temperatur dan faktor lainnya.dengan adanya pelepasan fosfat sehingga menjadi tersedia bagi tanaman sehingga berpengaruh terhadap pertumbuhan dan produksi tanaman..

Pada pengamatan berat kering tanaman perlakuan P3 memiliki berat tertinggi bila dibandingkan dengan perlakuan yang lainnya, peningkatan berat kering tanaman yaitu sebesar $58.11 \%$ bila dibanding dengan kontrol. Solisbury dan Ross (1995) mengemukakan bahwa $\mathrm{P}$ sangat berpengaruh terhadap perkembangan dan pertumbuhan tanaman karena $\mathrm{P}$ merupakan bagian esensial dari banyak gula fosfat pada nukleutida, seperti DNA dan RNA, serta bagian dari fosfolipid pada memberan. Perlakuan P2 memiliki P-tersedia tertinggi bila dibandingkan dengan perlakuan kontrol, peningkatan P-tersedia $42.27 \%$ lebih tinggi bila dibandingkan dengan kontrol . pada pengamatan Produksi tanaman kentang perlakuan P1 memiliki produksi tertinggi bila dibandingkan dengan perlakuan yang 
lainnya, peningkatan produksi tanaman yaitu sebesar $31.11 \%$ bila dibanding dengan kontrol. Produksi menurun dengan meningkatnya dosis pupuk $\mathrm{P}$ yang diaplikasikan. Sebagian P sangat berkaitan dengan pati, terutama dalam biji-biji serealia dan juga pada pati dalam umbi kentang (Marschner, 1986)

Tabel 1. Rataan P-Tersedia , Berat Kering Tanaman dan Rataan Produksi Tanaman Kentang Perlakuan Talaromyces pinophilus dan Dosis Pupuk P

\begin{tabular}{ccccc}
\hline Perlakuan & $\begin{array}{c}\text { P-Tersedia } \\
(\mathrm{mgkg}-1)\end{array}$ & $\begin{array}{c}\text { Serapan P } \\
\text { tanaman(g) }\end{array}$ & $\begin{array}{c}\text { Berat Kering } \\
\text { Tanaman }(\mathrm{gr})\end{array}$ & $\begin{array}{c}\text { Produksi } \\
\text { /tanaman }(\mathrm{g})\end{array}$ \\
\hline Kontrol (sebagai Pembanding) & 80.13 & 2.56 & 13.18 & 610 \\
\hline T1 & Jamur Pelarut Fosfat & & \\
T2 & $125.01 \mathrm{c}$ & 3.65 & $20.85 \mathrm{bc}$ & 786.11 \\
T3 & $91.50 \mathrm{a}$ & 4.25 & $17.25 \mathrm{a}$ & 611.94 \\
& $105.08 \mathrm{~b}$ & 4.45 & $20.78 \mathrm{~b}$ & 590.71 \\
P1 & Dosis Pupuk P & & \\
P2 & 95.07 & 3.65 & $18.36 \mathrm{a}$ & 800.14 \\
P3 & 114.31 & 4.26 & $19.68 \mathrm{ab}$ & 514.17 \\
& 112.21 & 4.44 & $20.84 \mathrm{bc}$ & 683.41 \\
T1P1 & KOMBINASI & & \\
T1P2 & 108.88 & $2.87 \mathrm{a}$ & $22.09 \mathrm{efgh}$ & $776.25 \mathrm{~cd}$ \\
T1P3 & 137.54 & 3.85 & $19.41 \mathrm{cde}$ & $679.5 \mathrm{bc}$ \\
T2P1 & 128.62 & $4.24 \mathrm{bc}$ & $21.04 \mathrm{efg}$ & $902.5 \mathrm{e}$ \\
T2P2 & 75.73 & $4.74 \mathrm{~cd}$ & $14.34 \mathrm{a}$ & $1017.5 \mathrm{f}$ \\
T2P3 & 95.80 & $3.47 \mathrm{ab}$ & $16.94 \mathrm{bc}$ & $618.75 \mathrm{~b}$ \\
T3P1 & 102.96 & $4.53 \mathrm{bc}$ & $20.47 \mathrm{cdef}$ & $699.58 \mathrm{c}$ \\
T3P2 & 100.61 & $3.34 \mathrm{a}$ & $18.65 \mathrm{bcd}$ & $606.67 \mathrm{ab}$ \\
T3P3 & 109.58 & $5.45 \mathrm{de}$ & $22.70 \mathrm{fgh}$ & $544.17 \mathrm{a}$ \\
\hline a & 105.06 & $4.56 \mathrm{~cd}$ & $20.99 \mathrm{def}$ & $648.33 \mathrm{ab}$ \\
\hline
\end{tabular}

Ket : Angka - angka pada baris dan kolom yang diikuti huruf kecil menunjukkan pengaruh nyata pada taraf 5\% menurut uji BNT.

Kombinasi perlakuan Jamur pelarut fosfat ( $T$. pinophilus )dan SP36 berpengaruh terhadap peningkatan $\mathrm{P}$ tersedia pada perlakuan J1P2 yaitu sebesar $71.65 \%$ bila dibanding dengan kontrol walaupun secara statistik tidak berpengaruh nyata. Pada parameter serapan $\mathrm{P}$ tanaman aplikasi perlakuan $T$. pinophilus dan SP36 berpengaruh nyata dalam peningkatan serapan $\mathrm{P}$ tanaman, perlakuan yang terbaik adalah T3P2 tetapi menurun dengan peningkatan dosis SP36 $(\mathrm{P} 3=13 \mathrm{~g}) \quad$ (Gambar 1). Berat kering tanaman perlakuan T3P2 yang terbaik dan menurun dengan meningkatnya dosis SP36 (13 g) (Gambar 2). Peningkatan produksi tanaman kentang yang tertinggi yaitu J2P1 dengan produksi sebesar $1017.5 \mathrm{~g}$ sedangkan tanaman kontrol 610 g.Peningkatan produksi tanaman kentang yaitu sebesar $66.8 \%$ lebih tinggi bila dibanding dengan kontrol. Aplikasi $T$. pinophilus sebanyak $20 \mathrm{~mL}$ dan $6.5 \mathrm{~g}$ SP36 memiliki produksi yang terbaik, produksi menurun dengan peningkatan 
dosis T. pinophilus dan pupuk SP36 (Gambar 3).

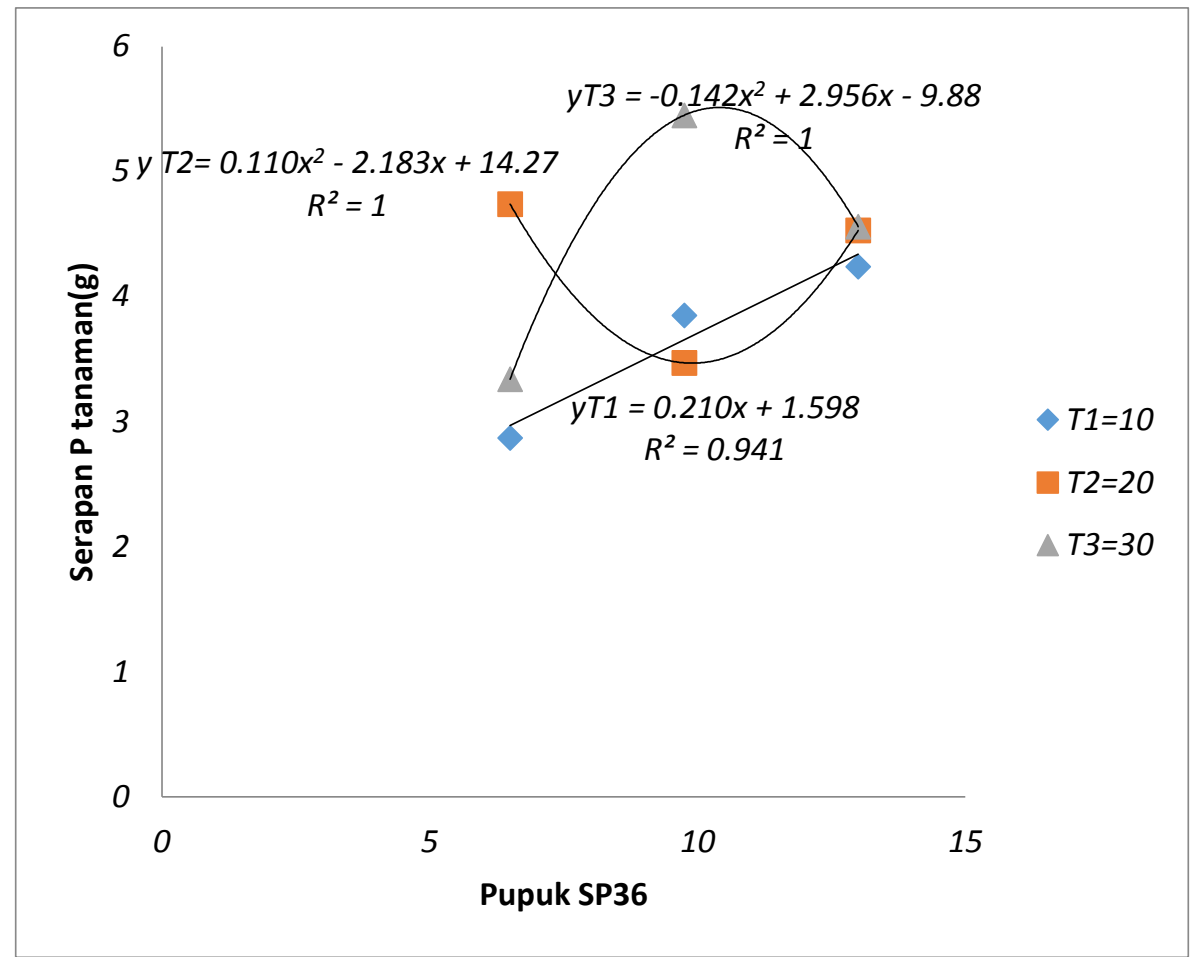

Gambar 1. Hubungan antara Talaromyces pinophilus dan SP36 terhadap Serapan P Tanaman

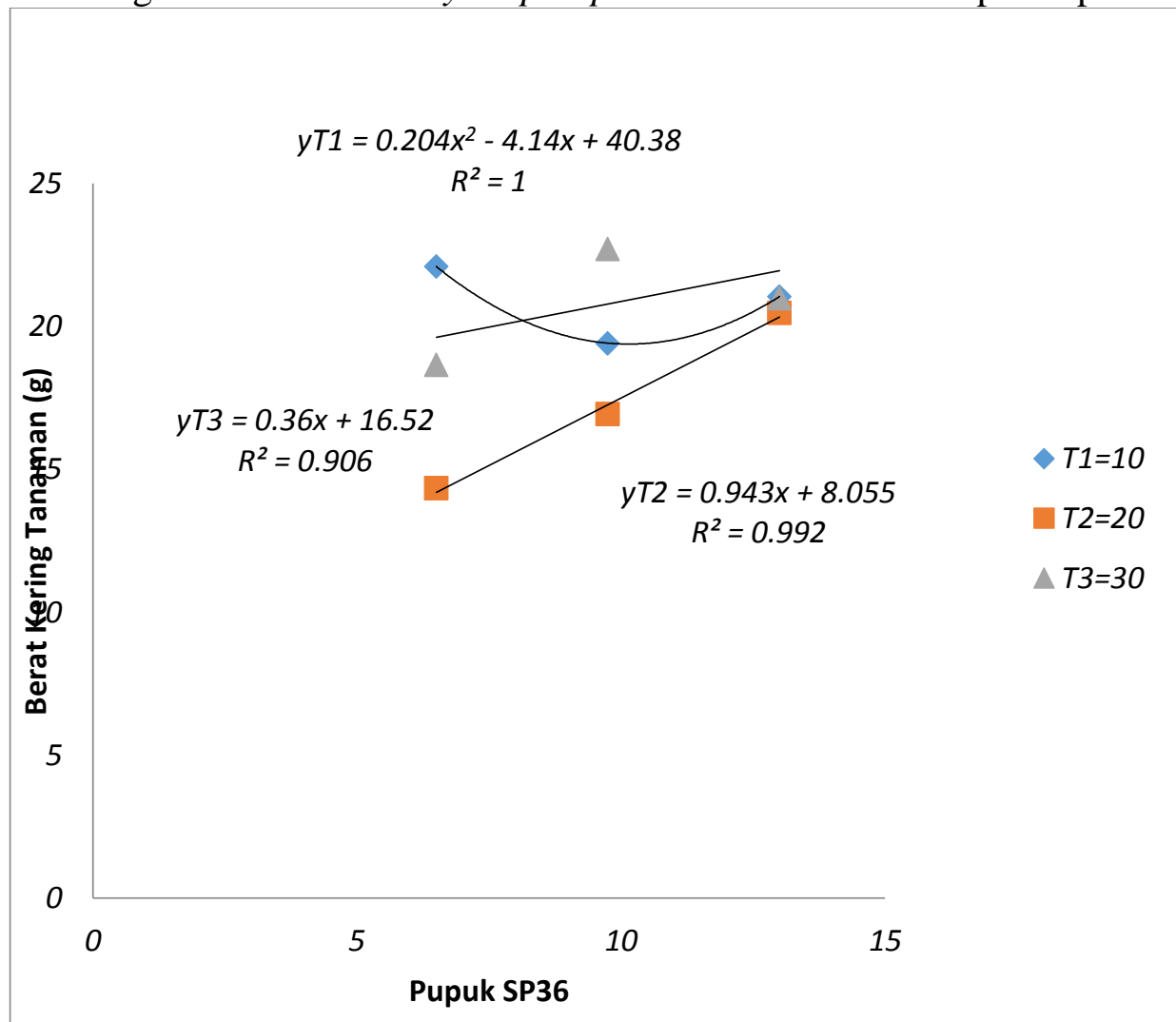

Gambar 2. Hubungan antara Talaromyces pinophilus dan SP36 terhadap Derat KeringTanaman 


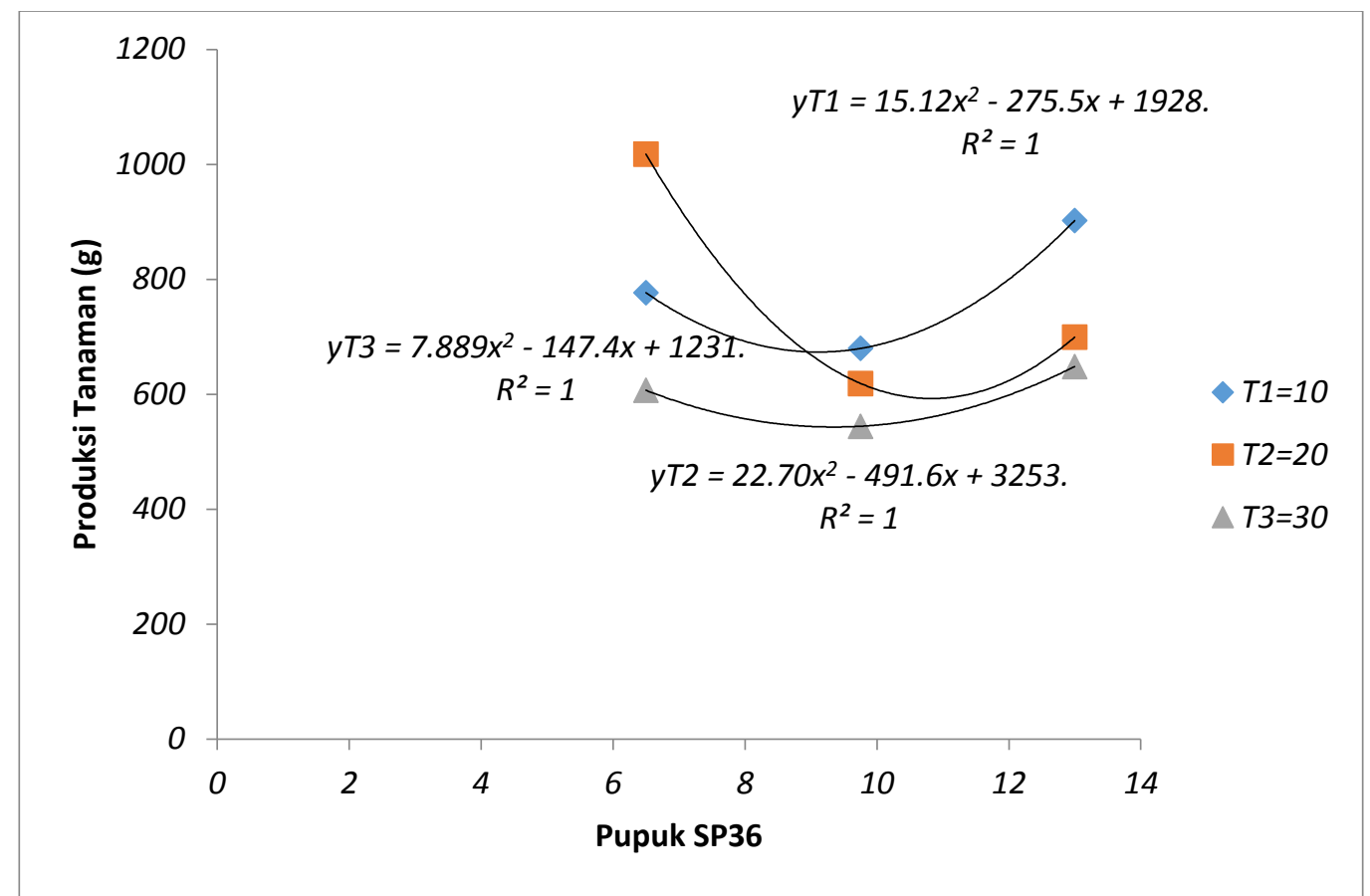

Gambar 3. Hubungan antara Talaromyces pinophilus dan SP36 terhadap Produksi Tanaman

\section{SIMPULAN}

Aplikasi jamur pelarut fosfat dapat meningkatkan pertumbuhan tanaman, Ptersedia, serapan $\mathrm{P}$ tanaman dan produksi tanaman, secara umum perlakuan yang terbaik adalah $\quad \mathrm{J} 1$ dengan dosis $10 \mathrm{ml} /$ Tanaman. Aplikasi Dosis pupuk $\mathrm{P}$ dapat meningkatkan pertumbuhan tanaman, P-tersedia, serapan $\mathrm{P}$ tanaman dan produksi tanaman, secara umum perlakuan yang terbaik adalah P1 dengan dosis 6.5 gr SP36/Tanaman..

Aplikasi jamur pelarut fosfat dan Dosis Pupuk $\mathrm{P}$ dapat meningkatkan pertumbuhan tanaman, P-tersedia, serapan $\mathrm{P}$ tanaman dan produksi tanaman, perlakuan yang terbaik adalah J1P3 dengan dosis jamur pelarut fosfat 10 $\mathrm{ml} /$ tanaman dan dosis pupuk $\mathrm{P}$ sebanyak 13 gr SP36/ tanaman.

\section{DAFTAR PUSTAKA}

Balitbangtan. 2014. Hasil Kajian dan Identifikasi Dampak Erupsi Gunung Sinabung pada Sektor Pertanian. Badan Penelitian dan pengembangan pertanian.

Kementrian pertanian.

Buckman, H.O dan N. C. Brady. 1982. Ilmu Tanah. Penerjemah: Soegiman.Terjemahan dari: Soil Science. Bhratara Karya Aksara. Jakarta. 788 hal.

Darmawijaya, M.I. 1990. Klasifikasi Tanah. Balai Penelitian Teh dan Kina. Bandung.

Ditjen Hortikultura , 2010. Pedoman Umum Pelaksanaan Pengembangan Hortikultura Tahun 2011. Kementerian Pertanian Direktorat Jenderal hortikultura.

Havlin, J.L., J.D. Beaton., S.L. Tisdale and W.L. Nelson. 1999. Soil Fertility and Fertilizer. An Introduction to Nutrient Management. Sixth ad. Prentice Hall, New Jersey.

Marschner, H. 1986. Mineral Nutrition of Higher Plants. Academic Press Harcourt Brace Jovanovich, Publisher. London.

Muklis. 2013. Penyusunan Amandemen Silikat Berdasarkan karateristik Tanah Andisol Gunung Sinabung. Disertasi Program Doktor Ilmu Pertanian. Fakultas Pertanian USU. 
Sahar Hanafiah,A., Sabrina dan Guchi,H. 2009. Biologi Dan Ekologi Tanah. Fak. Pertanian USU. Medan

Sanchez, P.A. 1992. Sifat dan Pengelolaan Tanah Tropika. (Trnsl, Johana T. Jayadinata) dari judul asli.
Siefferman, U. 1992. Mineralogi Lempung. (Tidak dipublikasikan) Fakultas Pascasarjana UGM. Yogjakarta. 